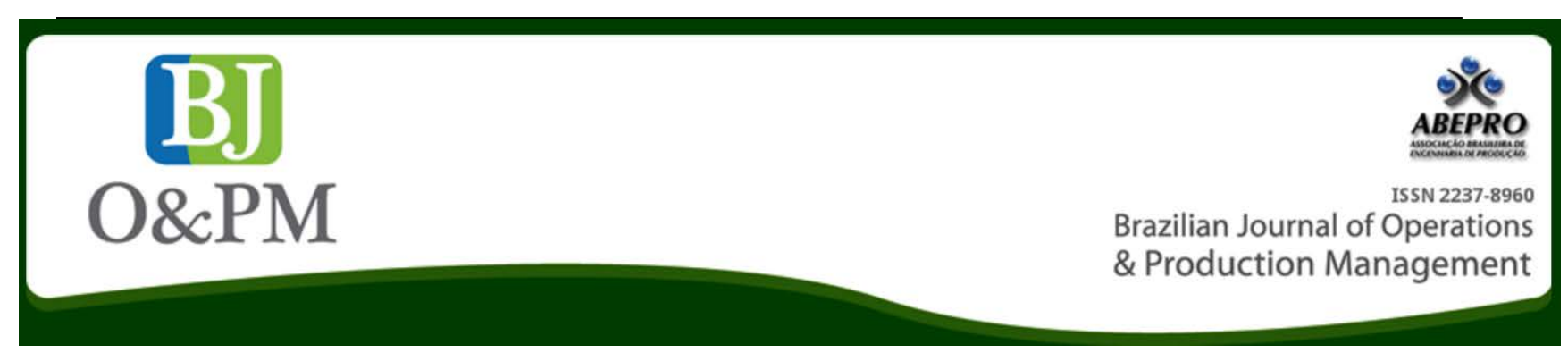

\title{
ADVANCED PLANNING SYSTEMS (APS) FOR SUPPLY CHAIN PLANNING: A CASE STUDY IN DAIRY INDUSTRY
}

\author{
Cecília Farid Zago ; Marco Aurélio de Mesquita ${ }^{a}$ \\ ${ }^{a}$ University of São Paulo (USP), São Paulo, SP, Brazil
}

\begin{abstract}
This paper discusses which benefits the use of APS may bring to the S\&OP, and the critical factors for the successful implementation. A case study was conducted in a major dairy company in the Brazilian food industry. Positioned in an environment of high market competition and narrow profit margins, the company strives for operational excellence, aimed at inventory reduction and increased service level. This supply chain includes several plants and has recently been through the deployment of an APS to support its S\&OP process. The research has identified the main benefits of the APS: greater confidence and accuracy in planning, and better balancing of inventory throughout the supply chain. The deployment project went through specific difficulties that delayed its schedule. The study reinforces the importance of fully support from senior managers and the commitment of the planning staff to meet the challenges of customization and integration of the new system.
\end{abstract}

Keywords: APS, S\&OP, critical success factors, food industry.

\section{INTRODUCTION}

Companies find themselves nowadays in an increasingly demanding market, which requires continuous improvement in their process and turns the decision-making activities even more elaborate.

In the industry of dairy products, the competitive context is not different, and it is worse by the fact that raw material and finished products are perishable. That requires more assertiveness in the planning and operation of this supply chain. In spite of the characteristics of commodity of most dairy products, they demand a price gap and, hence, a differential in costs of production and distribution from the companies in the sector.

To keep themselves competitive in this environment, the firms need reliable information systems and advanced tools for decision-making. Thus, the companies invest in the deployment of Decision Support Systems (DSS). Advanced Planning Systems (APS) are one kind of DSS focused on operations management.
Saphiro (2001) classifies information systems in analytical and transactional. The transactional systems manage the flow of information through the supply chain, like the ERP (Enterprise Resource Planning) systems, whilst the analytical systems, like APS, perform calculations that allow the analysis of the supply chain performance through mathematical models and measures that guide the decision-making.

The implementation of ERPs has as goal to integrate in one only platform the multiple processes of a company, facilitating the data flow. Maguire et al.,(2010) have analyzed the process of implementation of ERPs. Others have pointed out the risks and critical success factors for the implementation of those systems, such as Hakimet Hakim (2010), Françoise et al., (2009), Díez et Mcintosh (2009).

As to the APS, when configured and deployed, they are placed in a different context, concerning the systematization of the decision-making process. The APS, as explained by Courtney (2001), despite having been originally conceived to solve semi structured problems, are broadly utilized by companies to solve problems in the tactical planning level, in which parts of knowledge are not structured. That 
brings complexity to the process of implementation of these systems. The APS includes models and methods of Operations Research to support decision-making (Stadtler, 2005).

APS systems can support decisions of different planning hierarchies. They are used in more operational levels like scheduling and inventory control, also in tactical levels of planning as in the Sales and Operations Planning (S\&OP), or even in strategic level in the definition of the supply chain. According to its usage, the patterned problems are more or less structured, giving the system a bigger or smaller degree of customization.

Ivert et Jonsson (2010) studied the potential benefits of APS in the process of S\&OP and listed them in three groups: decision support; efficient planning and knowledge building. Chou et al.,(2012) present a model for Master Production Scheduling (MPS) in use of APS that provided improved results in the simulated scenarios. Entrup (2005) shows application of APS in three food companies and discusses the specificities of the planning process of such industry.

Faé et Erhart (2009) report that APS can bring positive results to companies, however the process of implementing involves a series of challenges to be well succeeded. The rate of unsuccessful information systems implementation projects is still high. According to a research published in the Chaos Report, by the Standish Group International, the rate of failure in projects of Information Technology was of $24 \%$ in 2009.

This paper reports a case study done in a big Brazilian company in the dairy products sector, who owns several factories and brands. This sector of Brazilian agribusiness has an extremely pulverized production chain, with squeezed contribution margin, resulting in strong demanding for operational efficiency. Thus, it is crucial to have a planning that balances in an optimized manner the demand of the market and the constraints of the operations in the company's sundry industrial unities.

The coordination of the planning process takes place in the process of S\&OP. The operation of the company's entire network is planned, considering the production and distribution in its 12 plants. This planning process runs with the support of a management information system. As there are planning problems which can be wrought and solved by the use of Operations Research, the APS systems are proper for this type of appliance.

It is the goal of this paper to identify benefits brought to the S\&OP process by the utilization of APS systems. Besides, it intends to survey the main safety measures to be taken during the implementation of the system and the critical success factors in the stages of selection, development and utilization. This aims to create a theoretical contribution to the field of Advanced Planning Systems implementation.

\section{THEORETICAL FRAMEWORK}

In this section, we present basic concepts related to information technology and decision support models for managing the supply chain, including project management of these systems in businesses.

\subsection{Management Information Systems}

The utilization of information technology as a competitive differential has a very relevant role to the organizations of current markets. The information systems are covered in this section in a more comprehensive perspective, embracing technological and organizational aspects.

According to Laudon et Laudon (2012), an information system comprises components that collect, process, store and distribute information that will support decision-making and control over the organizations. In this way, information systems include three different aspects: organization, technology and people. They can be classified according to the level in which the decision occurs, altogether represented in Figure 1.

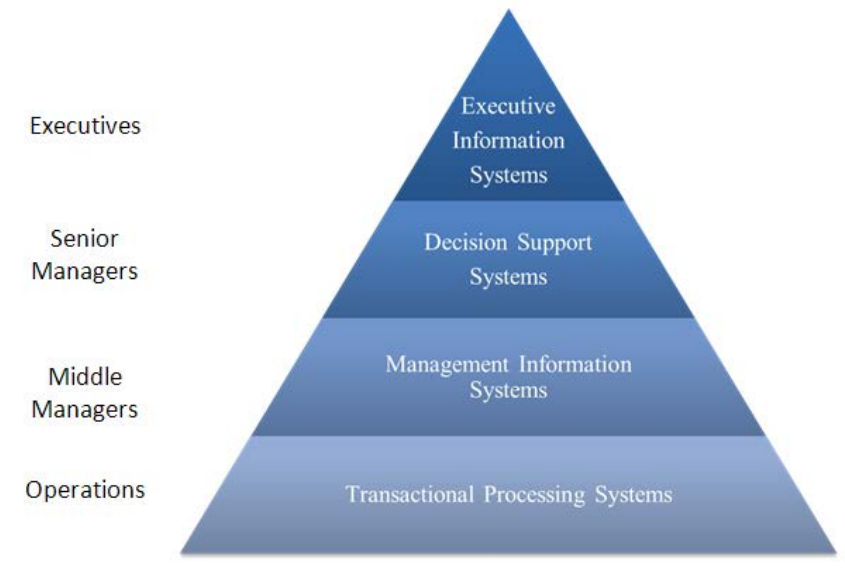

Figure 1: Four level pyramid model of information systems (O'Brien \& Marakas, 2010)

On the operational level, systems must assist the control and tracking of the company's basic transaction activities. For this reason they are called Transactional Processing Systems (TPS). They routinely register the firm's information (Laudon et Laudon, 2012). 
The information on sales orders established with customers, production orders for the shop floor, inventory tracking, and receipt of products purchased from external suppliers, are all transactional information generated in the day to day business. Hereinafter, TPS are important monitoring tools.

In the management level are the Management Information Systems (MIS) and Decision Support systems (DSS), which oftentimes integrate the data from the TPS and translate them into information that will provide the basis for the decision-making. DSS provides data analysis tools for processing and formatting great quantities of data to be used by decision makers (Laudon et Laudon, 2012).

As for the Executive Information Systems (EIS), they are used to strategic decision making in the long-term. These are systems that incorporate data from external environments, to analyze movements that might affect the competitiveness of the company, in addition to internal DSS information (Laudon et Laudon, 2012).

\subsection{Advanced Planning Systems (APS)}

APS systems are characterized by the support of decision-making in strategic, tactical and operational levels simultaneously. On these three levels of planning, the problems to be solved are complex and oftentimes little structured. That requires advanced models and makes APS utilization relevant in industrial environment. Figure 2 presents APS systems' structure.

The purpose of an APS is to develop and integrate already known models and methods in the field of Operations Research to support Logistics and Production Planning and Control decisions. These systems allow decisions in all levels of planning hierarchy to be based in mathematical programming and heuristics (Stadler, 2005). Yet, APS do not emerge as substitutes for Enterprise Resource Planning (ERP), but as their complement. Generally in ERP, transactions are processed and stored in databases, whilst APS are built to support decisions in the long-, mid- and short-terms of planning.

On the tactical level, with a time horizon of usually three to twelve months, the Demand Planning and the Aggregate Production Planning (APP) are made. They will structure the Sales and Operations Planning (S\&OP) process. Based on the future sales forecasts, begotten by the management of the demand, aggregate analyses of capacity balancing are created and translated into plans for the next periods. These plans should be agreed between sales and operation and can consider more than one factory plant, as is the case in the present case study.

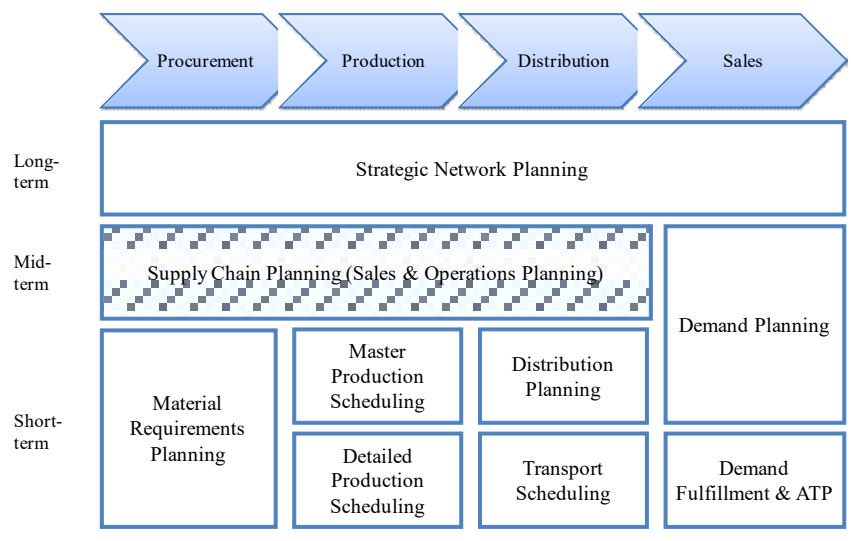

Figure 2: APS Modules Structure (Source: adapted from Fleischmann et al., 2005)

The breakdown of the aggregate planning shall take place in the short-term, with an average time horizon of one or two months, by means of a Master Production Scheduling (MPS). At this point the demand for materials is calculated usually by utilizing the logics of Material Requirements Planning - MRP (Entrup, 2005).

Then, information of the master schedules is unfolded to the short-term planning. The detailed production scheduling is made by means of finite capacity models, considering lead times, lot sizes and purchases orders. As to distribution scheduling, in which on can apply routing models to the management of sales orders, the Available to Promise (ATP) model can be used. According to Cox et Blackstone (2005) ATP refers to the quantity (stocked or planned to be produced) that is not yet compromised with orders from customers.

\subsection{S\&OP}

In the present case, there is a complex decision-making in the tactical-operational levels with great impact in the financial result of the company. It takes place in the S\&OP process, which evaluates the demand and production capacity of factory plants and distribution centers of the whole supply chain.

In spite of the significant evolution of companies through the integration of their supply chains, there is still room for optimization of profits in what concerns the integrating its sales, operations and finance. The S\&OP process covers this context (Grimson et Pyke, 2007). A functional integration of the areas is possible since their drivers are all balanced and synchronized. That allows it to add value in the management of the supply chain (Feng et al., 2008).

Under Grimson et Pyke (2007), this process is held in five steps: firstly the sales forecast is updated. Then, the necessary information is surveyed among the operational areas: inventory strategies, production chain capacity 
and internal procedures. The S\&OP area must crosscheck this information with the guidelines and so formulate the Aggregate Production Planning. The third stage of the process, as defined by the authors, is the arrangement of formal meetings to establish consensus on the developed plan. In those for, the senior management is involved in analyzing the main indicators for decision-making. The fourth step is the unfolding of the plan for the operational and sales areas. At last, the fifth step refers to the tracking and measuring of the S\&OP process.

\subsection{Soft Systems Methodology (SSM)}

The concepts of SSM tackled in this topic may help the case study, which deals with the deployment of an APS. The system is focused on the S\&OP process and strongly supported by mathematical programming with high degree of customization.

SSM is a methodology of systematic approach that represents through system models the perception of the world events. Whilst systems of exact methodologies are geared to reach determined goals, SSM is a learning system, a process of management (Checkland, 1989).

The way of studying systems is divided into two complementary approaches, commonly called "hard" and "soft". SOFT: concerns unstructured problems, involving human and cultural considerations. HARD: regards solving technical and well defined problems.

SSM uses the concept of "holon", referring to "human activity system", that is, connected activities that represent the idea of a whole. In soft systems, the process of investigation of the events can itself create holons. On the other hand, hard systems consider that the studied universe already contains holons. From that, a range of models are created to represent the real world, assuming for that matter that different individuals are going to evaluate the facts differently, leading to distinct actions.

Checkland et Scholes (1999) defined four main activities that structure the methodology:

1. Detecting the problems,

2. Drafting relevant activity models,

3. Debating the situation, using models that discuss: the changes that could contribute to improve the situation and the arrangement among the conflicting interests that could enable an improvement action to be taken,

4. Taking an improvement action.

The learning cycle of SSM comprises seven stages, illustrated by Figure 3 .

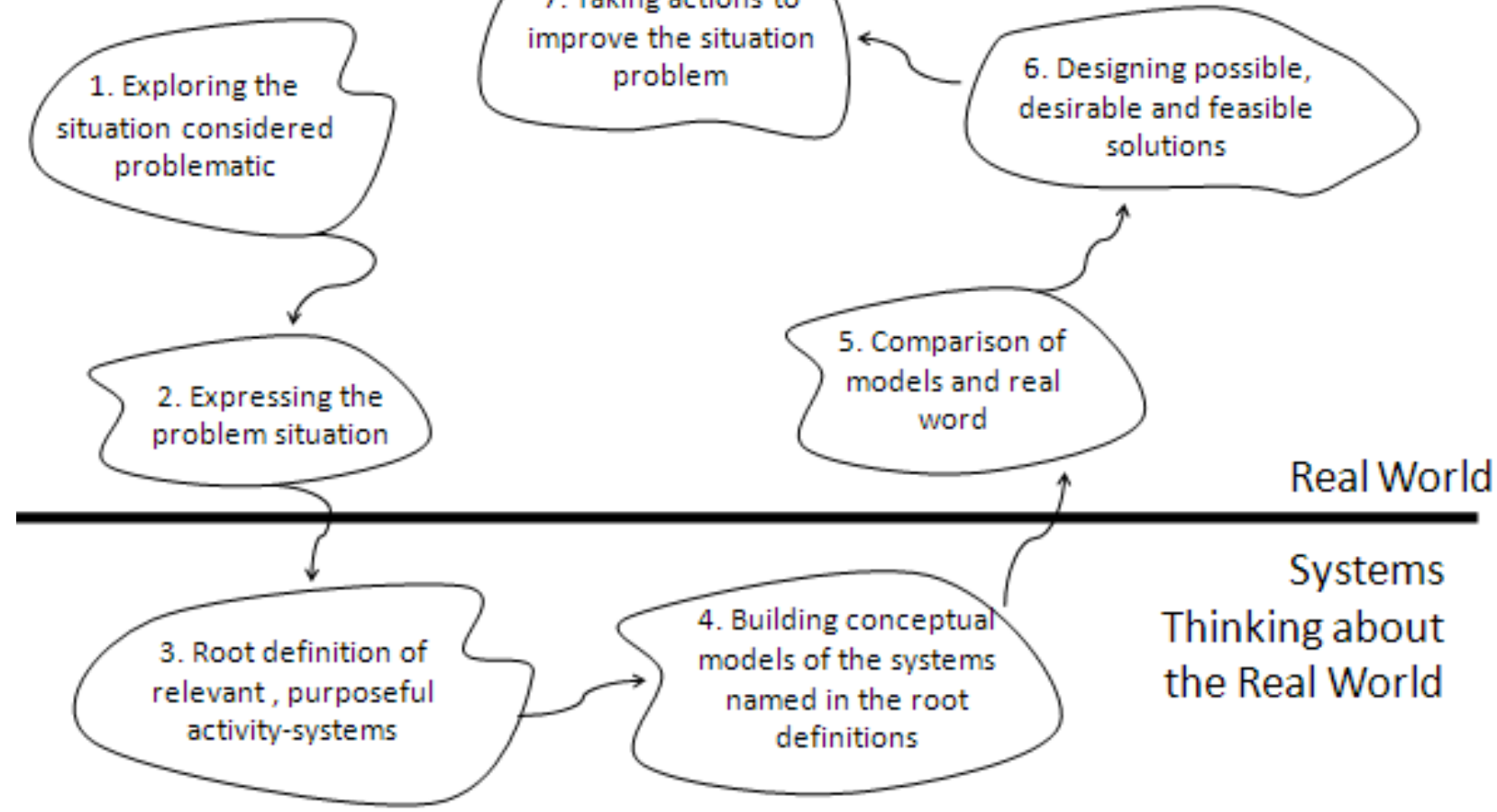

Figure 3: Learning cycle of SSM (Source: adapted from Checkland, 1999). 


\subsection{Implementation of Information Systems}

Rockhard (1979) developed a study with the greatest businessmen of that time, listing from them which were the biggest needs of information and comparing them to the existing ones in information systems. For this survey, one proposed method was of Critical Success Factors (CSF), which showed to be very efficient in listing the requirements of information of companies.

According to Rockhard (1979), CSF are a limited amount of factors that must be carefully managed to ensure success and competitiveness to the organization. The author classifies CSF either as "monitoring" or "building", varying with the context in which the companies operate.

Since then, the methodology has been used in projects development and implementation of information systems to increase their chances of success. According to Albertin (1996), it is crucial that the deployment of an information system is in accordance with the usage strategy of such technology in the organization, hence, the firm's business strategy.

A series of studies has been done concerning the survey of CSF in implementation of information systems projects. Poon et Wagner (2001) carried out six case studies in information systems development to identify how CSF were treated. Umble et al., (2003), motivated by the big quantity of failed implementation cases of ERP, listed their CSF and presented a successful case, analyzing it from the key success factors aspect.

Finney et Corbett (2007) explored the literature regarding CSF concerning implementation of ERP and ranked the factors by the frequency they were approached in previous studies. Thereby, their ratings were compiled in Table 1.

Table 1: Critical Success Factor in ERP implementation.

\begin{tabular}{|l|r|}
\hline \multicolumn{1}{|c|}{ Critical Success Factor } & \multicolumn{2}{c|}{$\begin{array}{c}\text { Number of } \\
\text { times quoted } \\
\text { in literature }\end{array}$} \\
\hline $\begin{array}{l}\text { Support and compromise from senior } \\
\text { management }\end{array}$ & 25 \\
\hline Change management & 25 \\
\hline Process reengineering & 23 \\
\hline Work redesign and training & 23 \\
\hline Selection of work team & 21 \\
\hline Implementation strategy and deadline & 17 \\
\hline Selection and relationship with & 16 \\
consultant & 15 \\
\hline Vision and planning & 12 \\
\hline Qualified staff & \\
\hline
\end{tabular}

\begin{tabular}{|l|r|}
\hline $\begin{array}{l}\text { Presence of an effective leader } \\
\text { (champion) }\end{array}$ & 10 \\
\hline Communication plan & 10 \\
\hline Infrastructure & 8 \\
\hline Cultural change management & 7 \\
\hline Post-implementation evaluation & 7 \\
\hline Software selection & 7 \\
\hline Crew motivation & 6 \\
\hline Minimal customization & 6 \\
\hline Project management & 6 \\
\hline Troubleshooting management & 6 \\
\hline Legacy System consideration & 5 \\
\hline Data conversion integrity & 5 \\
\hline System testing & 5 \\
\hline Customers consulting & 5 \\
\hline Management of project and involved & 5 \\
\hline costs & 3 \\
\hline Business case building & 3 \\
\hline Strong decision-makers & \\
\hline
\end{tabular}

There are in the literature some works about APS systems implementations. Entrup (2005) presents in his work the application of APS systems in the food industry, investigating which are the requirements of the system in the context and how one can deal with shelf life restriction.

Ivert et Jonsson (2010) have conducted a survey on the potential benefits of APS in the process of S\&OP. Based on case studies in the chemical industry, the authors have come to the main groups of benefits: effects on learning and knowledge of the process, greater efficiency in planning, advantages of the decision-making support.

Giacon et Mesquita (2011) surveyed the detailed production planning practices, aiming to identify the needs, challenges and benefits of APS systems' implantation. Chou et al., (2012) proposed a model of APS to be used in the Master Planning and Scheduling process of a technology industry, having identified relevant benefits in the process.

Through literature review it can be concluded that there are many studies regarding Critical Success Factors in projects of ERP implementation, but the case of APS implementation is still little explored. There are differences on the implementation of these information systems that justify the importance of extending CSF studies also to APS implementation; they are systems that involve a bigger degree of customization, apart from analytical complexity of the decision-making process' structure. That makes the conduction of this study relevant. 


\section{RESEARCH METHODOLOGY}

This work intends to create a theoretical contribution that helps guiding the process of decisions support systems implementation to the S\&OP process. More specifically, its goal is to list potential benefits reached by the utilization of an APS in the process of tactical planning and to identify the main reasons for its implementation. Therewithal, the main difficulties of the implementation of APS will be identified, through the mapping of factors that can be considered critical to the project's success.

The case study method will be used to investigate this contemporary phenomenon and answer to the researcher's questions. The case study method allows a deeper analysis of the problem, stimulating its better understanding (Miguel, 2007).

In this paper, we consider the following general questions:

1. What are the potential benefits of APS implementation to the S\&OP process?

2. What are the critical success factors for the implementation of a customized APS to support S\&OP?

The research method is the study of one case, held with a major Brazilian company in the dairy products sector, providing a deeper approach of the event. Data collection can be made by combining more than one method, such as interviews, observations, documental analysis and questionnaires. Evidence analysis can be either quantitative or qualitative (Eisenhardt, 1989) and must always considers the context and the contemporary aspects of the case (Meredith, 1998). In this project, data collection has been done through interviews, direct observations and documental analysis. Figure 4 presents five steps for the conducting a case study (Miguel, 2007).

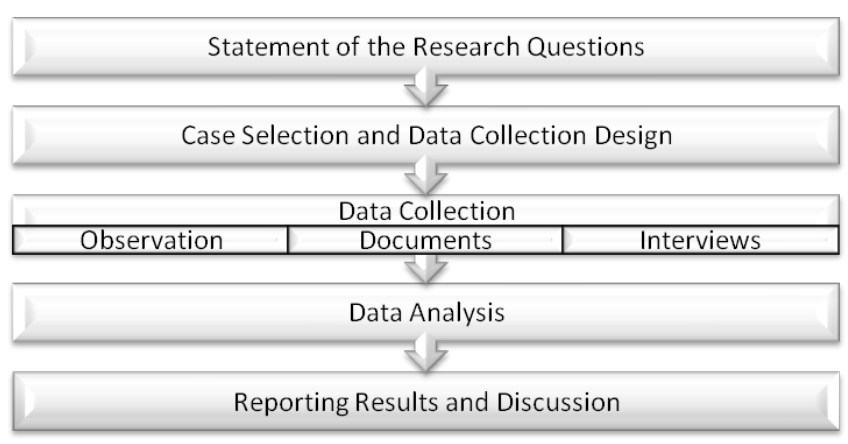

Figure 4: Basic steps for a case study (adapted from Miguel, 2007)

The two research questions presented in this section arose from the studied literature. To answer them, a case was selected that well represented the reality in observation: a major Brazilian company in the dairy products sector that has recently concluded the project of an APS system implementation to support its S\&OP process.
To guide data collection, two interview scripts were formulated. One to be applied to company employees and the other to be used with selected personnel of the consulting company that supported the implementation process. The results are shown in sections 4 and 5 .

\section{CASE STUDY}

The case study was conducted with a big Brazilian dairy products firm, which has more than ten factory plants in national territory and more than three thousand employees. It is present in Brazilian market with more than a hundred kinds of products and processes circa two billion liters of milk per year.

The manufacturing processes are deeply interconnected, which means that the elaboration of master production schedules must consider multiple unities of production. The planning environment of the company involves uncertainties both in demand for the final product as well as in supply of raw materials.

The fragmented market and the commodity characteristic of the main product result in a large portion of demand uncertainty. On the other hand, the uncertainty in the supply of raw material, due to variations in field productivity and high demand for this input, causes cross flow of raw material and finished product. Often, a plant has to meet the need of production or sale of another. In this scenario, a flexible model for aggregated production planning is necessary.

To coordinate the flow of materials and the operations in more than ten plants, the company established in 2011 a corporate area of S\&OP. Initially, the production planning process was made through an empirical method based only in spreadsheets, with no usage of mathematical models searching for optimization of the company resources.

Given to the complexity of the process, the numerous markets to attend, the short shelf life of the products and the opportunity of maximization of the results obtained with the whole operation, the need of an APS acquisition was identified to support logistical and production planning that takes place in S\&OP.

The current company is the result of a recent merger and has been operating for some time with three different ERP systems. The consolidation of operations and planning processes were still in progress when it was launched the project to implement the APS.

The S\&OP process takes place monthly, with a time horizon of two months. That means the planning operations of $m+1$ and $m+2$ are made, whereas $m+1$ is fixed whilst $m+2$ will be revisited in the next planning cycle. Figure 5 shows the macro flow of this process in its main stages. 
The planning area in cooperation with the trade area formulate the forecast of the demand, which, along with the forecast of total milk offer, initial inventories and available capabilities, compose the input data to the aggregate logistics and production planning.

The schedules of selling, producing, buying and distributing are validated in an executive forum, the council of S\&OP, in which the senior management of the company checks the coherence of tactical planning with the strategic guidelines of the firm.

The goal of this stage of aggregate logistics and production planning of S\&OP process is to create a production schedule for many factories, considering the distribution of raw materials and final products throughout the firm's network to better meet the demand, meaning maximum profitability.

\section{S\&OPCycle}

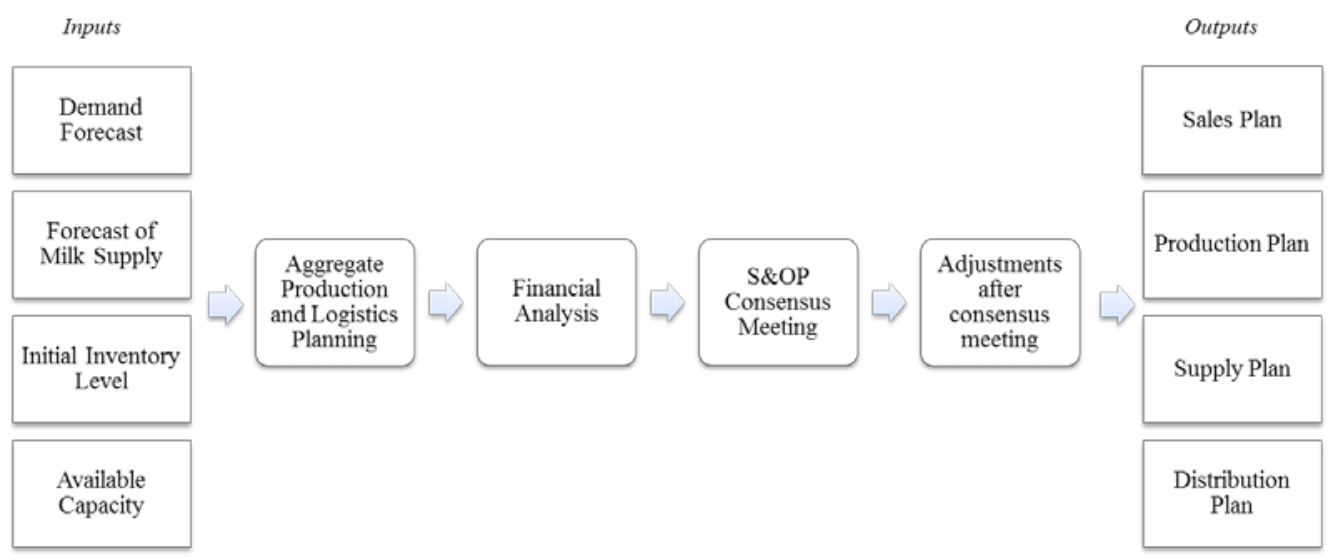

Figure 5: Representation of the S\&OP Process

For this to happen, the planning area counts with support from an APS system that uses linear programming to optimize balancing between production, inventory, sales and purchases. The implementation of this software is this work's object of study.

The APS in issue is a mathematical computing tool that searches maximization of the firm's operational profit. The system's programming is written in C language and the user's interface works by excel sheets, which facilitates scenario creation and edition. The amount of variables is flexible, whereas the bigger amount of them represents a bigger computing effort.

Figure 6 illustrates the production and logistics planning process through representing its SIPOC (Supplier, Input, Process, Output and Customer) diagram. In this diagram, it is described the monthly process, so their input parameters are updated monthly. The outputs of the process correspond to decision variables in consolidated reports that will comprise plans to procurement, production, distribution and sales.

\begin{tabular}{|c|c|c|c|c|}
\hline Supplier & Inputs & Process & Output & Customer \\
\hline Milk Supply & $\begin{array}{l}\text { Forecast of } \\
\text { Milk Supply }\end{array}$ & & Sales Plan & $\begin{array}{c}\text { Sales / } \\
\text { Marketing }\end{array}$ \\
\hline $\begin{array}{l}\text { Industrial } \\
\text { Management }\end{array}$ & $\begin{array}{l}\text { Available } \\
\text { Capacity }\end{array}$ & & $\begin{array}{l}\text { Production } \\
\text { Plan }\end{array}$ & $\begin{array}{l}\text { Industrial } \\
\text { Management }\end{array}$ \\
\hline Planning & $\begin{array}{l}\text { Inventory } \\
\text { Levels }\end{array}$ & $\begin{array}{l}\text { Aggregate } \\
\text { Production and }\end{array}$ & $\begin{array}{l}\text { Purchase } \\
\text { Plan }\end{array}$ & Milk Supply \\
\hline $\begin{array}{l}\text { Sales and } \\
\text { Planning }\end{array}$ & $\begin{array}{l}\text { Demand } \\
\text { Forecast }\end{array}$ & Planning & $\begin{array}{l}\text { Distribution } \\
\text { Plan }\end{array}$ & Logistics \\
\hline Sales & $\begin{array}{c}\text { Commercial } \\
\text { Issues }\end{array}$ & & $\begin{array}{l}\text { Project } \\
\text { Inventory } \\
\text { ATP }\end{array}$ & $\begin{array}{l}\text { Industrial, } \\
\text { Logistics \& } \\
\text { Sales }\end{array}$ \\
\hline
\end{tabular}

Figure 6: Aggregate Production and Logistics Planning Process. 
Once the analysis on the system's outputs is done by the planning area, the financial result is validated by the finances area. Aside the fact the result of the contribution margin is calculated by the APS, the information is not yet used directly by it. This represents an opportunity of improvement to the current process.

\section{RESULTS AND DISCUSSION}

This section presents the results of data collection taken in the case study, aiming at relating the information gathered with the hypotheses concerning the research questions of this study. The discussion will be based on three sources of evidence: interviews with people involved in the process, analysis of internal company documents and direct observation of the researcher. The collection of these sources of evidence occurred for about 6 months.

The interviews, which followed the script shown in Appendixes 1 and 2, were made with both company employees and the consulting staff who supported the deployment project. In total, five individuals were interviewed, three of the studied company and two of consultancy. From the consulting company, the CEO and the Senior Consultant were interviewed. From the client company, were interviewed the Chief Supply Chain Officer (main sponsor of the project), the S\&OP manager and the manager of milk supply (an important data supplier and customer for decisions in the APS deployment). In the next subsections the results of these interviews will be analyzed accordingly to the research questions.

\subsection{Potential benefits of APS in the process of S\&OP}

The first question this study aims to answer is: "What are the potential benefits APS systems can bring to a company's S\&OP process?"
Based on the interviews' answers, it can be deduced that the motivation for implementing an APS is a better integrated operation in the supply chain. It is agreed that it is possible to maximize the contribution margin, mainly through reducing variables in costs of inventory, transportation and tributes. Another improvement recalled by the interviewees is a better accuracy and agility to the firm's tactical planning.

At the time as the APS was being implemented, the company had more than one ERP in use. Until achieving the unification of ERPs platforms, using the APS as a decision support planning was considered unfeasible, and thus two projects were conducted in parallel, the development of APS and the integration ERP's.

The APS implementation project was concluded and integrated into the firm's S\&OP process. Thus, it has been possible to identify which of the expected benefits were reached. In general, the interviewees agree that the APS system meets the company's needs and provides appropriate solution for the operations planning.

Two of the respondents however believe that the deployment of the system was not consolidated as it should be and it could best be used, because there is still much room for improvement.

In terms of costs reduction, all the interviewed agreed it has helped reducing the inventory levels of final products, which can be confirmed by data in Figure 7. It is noteworthy that the valley in the middle of the year is due to the offseason milk.

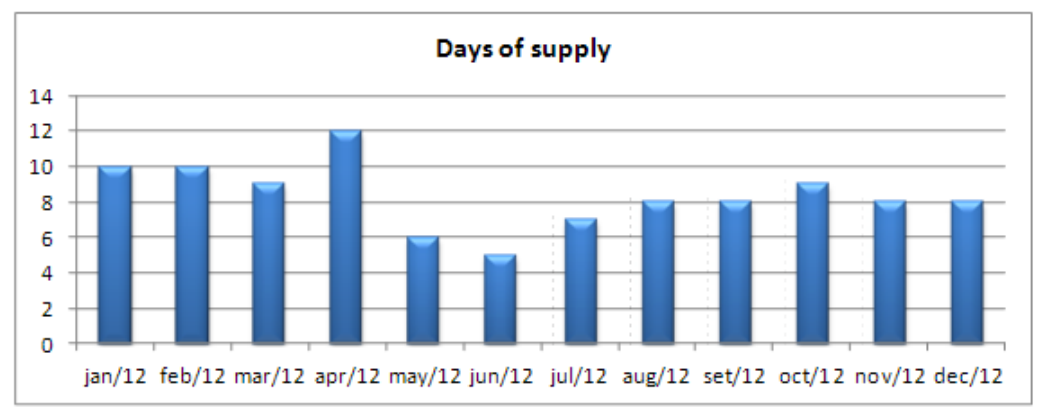

Figure 7: Inventory Tracking (Source: Company's Internal Data)

It is clear from the interviews' answers that APS systems favor planning process and facilitate new solutions testing, bringing agility to the process. As consequence, alternative scenarios can be achieved and compared with greater efficiency to the process of decision making.

Nonetheless, the financial analysis of each scenario is not 
made directly by the APS. The comparison between them is limited to analyzing operational indicators such as the sold quantity, inventory levels, and utilization of capacity. This fact was pointed in the interviews as an adverse factor to the comparison of different scenarios.

The usage of APS made the company's S\&OP process more stable, in that the areas involved have understood their role as suppliers or customers of the system, respecting the suggested plans. From the analysis of accuracy of the sales schedule, improvement in assertiveness of the 2012 year tactical planning can be perceived, as shown in Figure 8

This measurement of accuracy is calculated through the absolute difference between the sales schedule - defined in the S\&OP cycle from the forecast of demand - and the actual sales, in the same degree of aggregation used in planning. There is an improvement of 5 percentage points between the average of the first semester's indicator and the second's. That is due to the maturation of the project and better coordination in the chain.

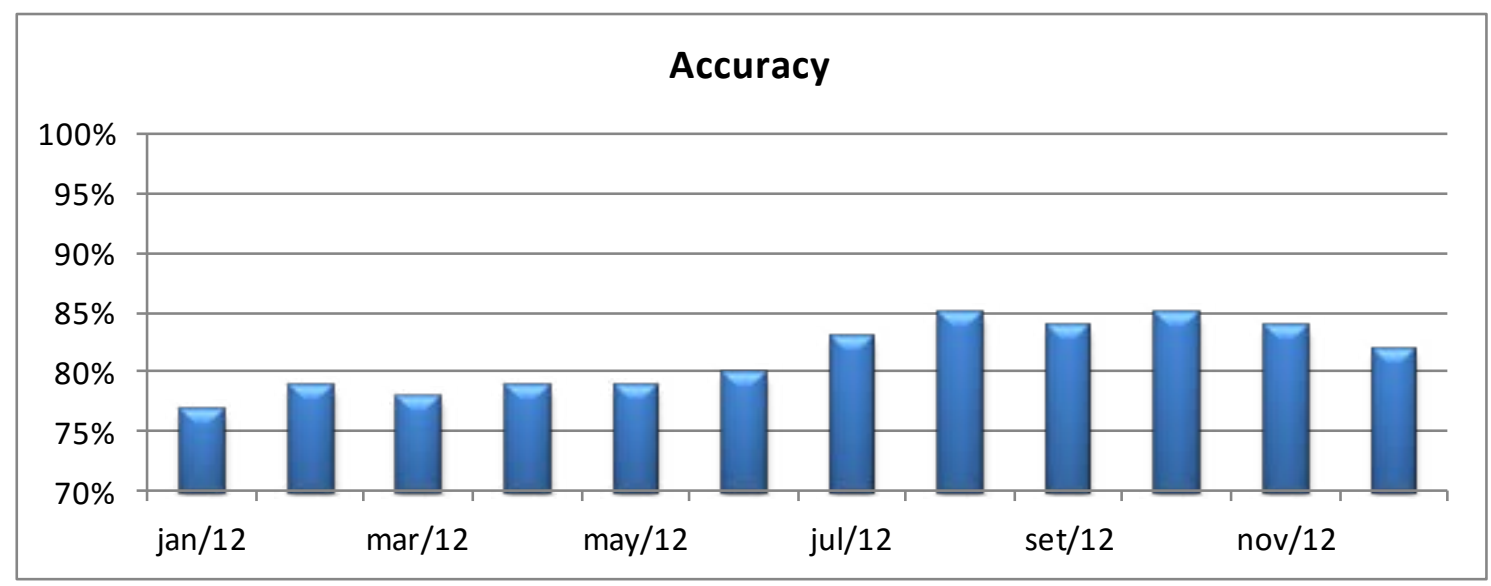

Figure 8: Sales Planning Accuracy (Source: company's internal data)

\subsection{Critical Success Factors in APS implementation}

To reach the benefits of APS, its project of implementation must be well conduced. CSFs guide the aspects that must receive more focus from the involved staff. In this research, CSF for APS implementation were divided in three groups, which also classify the hypotheses to answer the researcher's question on CSF:

- Company's Requirements, meaning: "the company that wishes to implement an APS system must be prepared to the change"

- Supplier Requirements: "the one to develop the system must be properly chosen"

- Project Management: "it is necessary to count with experience in managing information technology projects".

The results of data colleting regarding these factors will be presented in the following subsections.

\subsubsection{Company's Requirements}

In the studied case, it was possible to notice that the company went through a period of instability at the time of the APS system's implementation. That was due to a recent merger that had undertaken the company's energy in an implementation project with such a high degree of customization.

From the testimonials it has been possible to realize that the senior management had divergent opinions about the APS, hindering support from the high administration. Besides, the company's integrated operation was still in its beginning. The construction of their processes' documentation was on its initial phase, which hampered access to necessary data.

As to the evaluation and qualification of managing staff, all respondents believe that the company counted with well qualified collaborators. However, they have also agreed that people involved in the process had little time availability to dedicate themselves to an APS implementation.

Therefore the requirements of the company were the support from the high management, availability of qualified personnel and the presence of unified and reliable data. Those are listed as critical success factors for APS implementation and have affected the progress of this work's chronogram, resulting in its delay. Therefore, for the requirements of the company, support from upper management, availability of qualified personnel to conduct the project, the existence of unique and reliable data are listed as critical to the proper conduct of the implementation of an APS, and in the present case affected the schedule culminating in project delay. 


\subsubsection{Supplier's Requirements}

One of the most relevant factors in the choice of the consulting company as supplier was the fact that they had had previous experience with APS implementation in food industry. The company in issue had been the consultant for the implantation of the main dairy products firms' APS systems in Brazil. Thus it was considered that the company could add some important knowledge to the firm.

Another highly relevant factor for the selection of a supplier is the post-implantation support they offer. To evaluate this factor, the company staffs has contacted previous customers from the consulting firm and by so noticed satisfaction with their service.

The budget was also a factor in the consulting company choice. That was kept feasible for the firm's budget, while other consulting companies were discarded in consequence of having too high prices.

\subsubsection{Project Management}

The competence for managing IT projects involves some factors that are crucial to the success of the system's implementation:

- Scope and Goals: in the analyzed project, the goals were initially well defined. However, its scope has gone through some changes during the implementation. According to the manager responsible for the project, the changes of scope have resulted in the need to rework some stages.

- Chronogram: given the above mentioned changes, all interviewees agreed there has been a considerable delay on the chronogram. According to the consulting company, the consultants worked four months beyond the expected time.

- Training: the training offered by the company's employees was considered proper both by the responsible manager and by the interviewed consultants. Nevertheless, the number of trained people was insufficient. Only two people were skilled to operate the APS. A relevant matter that also affected the management of the tool was the high turnover faced by the company in 2011. In that way, an extra support from the consulting company was necessary, like training of new staff.

- Modeling: in spite of the company's complex planning problem, the system was considered to have well modelled and supported the decisions.

- Post-implementation support: the support from the consultants is considerate adequate. They maintain a 40-hours-per-month contract giving assistance to the users and updating to the system.
In this manner, it can be concluded that the interviews and direct observations of the case study answer to the second research question. The critical success factors were identified: support from high management, achievement of reliable data, time availability of the personnel involved and high turnover of the company at the time of implantation.

\section{CONCLUSION}

This paper intended to evaluate the benefits and risks associated to the implementation of APS systems in the process of production planning in a multi-plant chain in the dairy products industry. The APS in issue is supported by mathematical programming models for decision-making and has a high degree of customization. This customization is related to flexibility of modeling the problem (decision variables, constraints and objective), which makes the approach very similar to the SSM design methodology.

Regarding risks, beyond the usual critical factors for IT projects (top management commitment, effective project management, availability of reliable data, staff focused on the development of the project), the case study found the convenience of including professionals with training in mathematical modeling to better project progress.

In the case studied, the project of implementation of APS occurred in a setting of both internal instability related to post merger operations as related to the current market environment, making it difficult to objectively measure the benefits of deploying APS. Anyway, we observe factors that contribute to the successful implementation and can translate this success into positive outcomes for the operation.

The research was guided by two general questions. To the first: "What are the potential benefits of APS implementation to the S\&OP process?". The answer was that the main potential benefit is effectively optimizing the use of available resources. Those involved in the deployment process stated that the motivations of the project were focused on maximizing the contribution margin of the company and the first results show that the software has brought a reduction in costs. The reduction of inventory levels and freight costs were highlighted as promising.

Still referring to the first question, analysis of alternative scenarios is also highlighted as another benefit that motivated the deployment of the system. Compared to the previously used method of planning, APS has greatly facilitated the analysis of different scenarios and decision making. A remark that should be made is that the comparison between scenarios could be more efficient with the inclusion of financial reports directly as outputs of the system. 
To the second question: "What are the critical success factors for the implementation of a customized APS to support S\&OP?". The answer was that the main factors were related to the requirements of the company where the system was installed. It was noted that the necessary support from senior management was not done evenly and that there was involvement of only the part of the executive officers. In addition, the firm went through a post merger climate and the management system integration and unification hindered the necessary data collection.

Another aspect that hampered the company's readiness for change was that necessary personnel and their unabridged compromise weren't available. Apart from that, the high collaborators' turn over resulted in some fragility in management and knowledge of the tool.

This research project has limitations related to the employed methodology. The case study limits all generalizations to the reached conclusions, since they can't be unattached from their context. For future research, it would be interesting to extend this research to other APS implementation projects, so that the benefits and CSF deploying APS can be better defined.

\section{REFERENCES}

Albertin, A. (1996). Aumentando as chances de sucesso no desenvolvimento de sistemas de informação. Revista de Administração de Empresas, 36 (3), 61-69.

Checkland, P. (1981). System thinking, system pratice. Chichester: Wiley.

Checkland, P. (1989). Soft systems methodology. In J. Rosenhead (Eds.), Rational analysis for a problematic world. Chichester: Wiley.

Checkland, P., \& Scholes, J. (1999). Soft systems methodology in action. Chichester: Wiley.

Chou, C., Jen, C., Lin, K. \& Wen, W. (2012). Advanced Planning and Scheduling in a motherboard manufacturing industry. International Research Journal of Finance and Economics, 85, 26-39.

Courtney, J. (2001). Decision making and knowledge management in inquiring organizations: toward a new decision making paradigm for DSS. Decision Support Systems, 31, 17-38.

Cox, J. F., \& Blackstone, J. H. (2005). APICS Dictionary. 11 ed. Chicago: APICS.

Díez, E., \& Mcintosh, B. S. (2009). A review of the factors which influence de use and usefulness of information systems. Environmental Modeling \& Software, 24, 588-602.
Eisenhardt, K. M. (1989). Building theories from case study research. The Academy of Management Review, 14 (4), 532-550.

Entrup, M. L. (2005). Advanced planning and scheduling in fresh food industries. Berlin: Springer-Verlag Heidelberg.

Faé, C., \& Erhart, A. (2009). Desafios e tendências na aplicação de sistemas APS, Mundo Logística, 10, 52-60.

Feng, Y., D'Amours, S., \& Beauregard, R. (2008). The value of sales and operations planning in oriented strand board industry with make-to-order manufacturing system: cross functional integration under deterministic demand and spot market recourse. International Journal of Production Economics, 115, 189-209.

Finney, S., \& Corbet, M. (2007). ERP implementation: a compilation and analysis of critical success factors. Business Process Management Journal, 13 (3), 329-347.

Fleischmann, B., Meyer, H., \& Wagner, M. (2005). Advanced Planning. In H. Stadler, \& C. Kilger, (Eds), Supply Chain Management and Advanced Planning. Berlin: Springer.

Françoise, O., Bougault, M., \& Pellerin, O. (2009). ERP Implementation through critical success factors' management. Business Process Management Journal, 15, 371-394.

Giacon, E. \& Mesquita, M. A. (2011). Levantamento das práticas de programação detalhada da produção: um survey na indústria paulista. Gestão \& Produção, 18 (3), 487-498.

Grimson, J., \& Pyke. D. (2007). Sales and operations planning: an exploratory study and framework. The International Journal of Logistics Management, 18 (3), 322346.

Hakim, A., \& Hakim, H. (2010). A practical model on controlling the ERP Implementation risks. Information Systems, 35, 204-214.

Ivert, L., \& Jonsson, P. (2010). The potential benefits of advanced planning and scheduling systems in sales and operations planning. Industrial Management \& Data Systems, 110, 659-681.

Laudon, K. C., \& Laudon, J. P. (2012). Management Information Systems, 12 ed. New Jersey: Pearson.

Maguire, S., Ojiako, U., \& Said, A. (2010). ERP Implementation in Omantel: a case study. Industrial Management \& Data Systems, 110, 78-92.

Meredith, J. (1998). Building operations management theory through case and field research. Journal of Operations Management, 16, 441-454. 
Miguel, P. (2007). Estudo de caso na engenharia de produção: estruturação e recomendações para sua condução. Produção, 17 (1), 216-229.

O'Brien, J. A., \& Marakas, G. M. (2010). Management Information Systems. 10 ed. New York: McGraw-Hill.

Poon, P., \& Wagner, C. (2001). Critical success factors revisited: success and failure cases of information systems for senior executives. Decision Support Systems, 30, 393418.

Rockart, F. (1979). Chief executives define their own data needs. Harvard Business Review, 57 (2), 81- 93.

Shapiro, J. (2001). Modeling the Supply Chain. Pacific Grove: Brooks/Cole-Thomson Learning.

Stadtler, H. (2005). Supply Chain Management and Advanced Planning - basics overview and challenges. European Journal of Operational Research, 163, 575-588.

Umble, E, Haft, R, \& Umble, M. (2003). Enterprise resource planning: Implementation procedures and critical success factors, European Journal of Operational Research, 146, 241-257. 


\section{APPENDIX 1: GUIDE FOR INTERVIEWS IN THE CLIENT COMPANY}

The script shown below was used to interview employees of the client company, who were directly or indirectly involved in the project to implement the APS.

\section{Identification:}

Name:

Department:

Position:

Education:

Time working in the company:

Motivation for the APS Project:

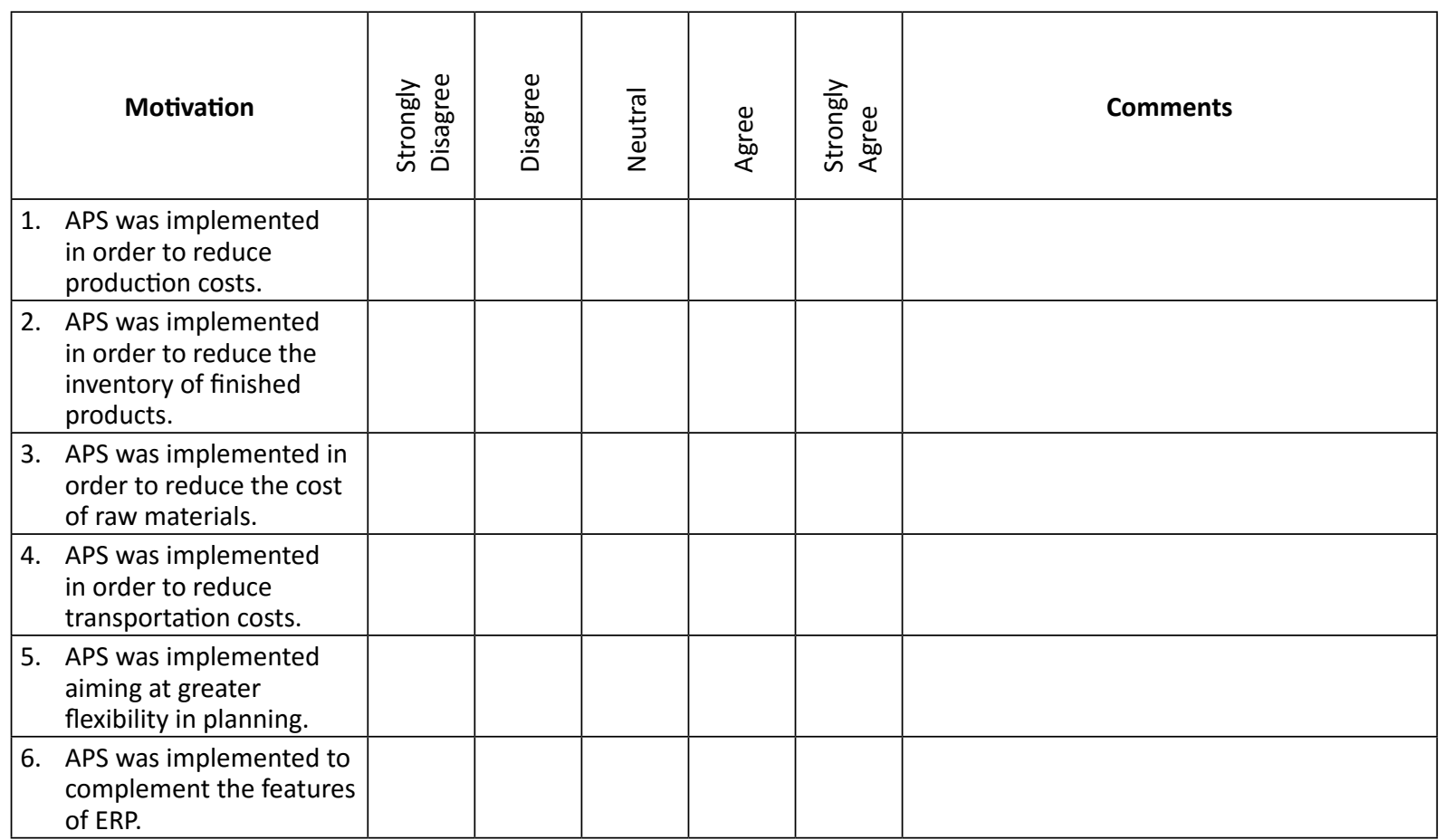

7. There were other motivations for the implementation of APS? What?

Critical Success Factors - Company Requirements

\begin{tabular}{|c|c|c|c|c|c|c|}
\hline Requirements & 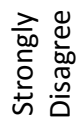 & 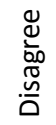 & 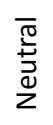 & 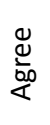 & 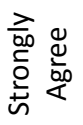 & Comments \\
\hline $\begin{array}{l}\text { 8. Senior management has } \\
\text { committed to the APS } \\
\text { project. }\end{array}$ & & & & & & \\
\hline $\begin{array}{l}\text { 9. The company shows } \\
\text { concern for operational } \\
\text { efficiency. }\end{array}$ & & & & & & \\
\hline $\begin{array}{l}\text { 10. The company had } \\
\text { qualified personnel to } \\
\text { manage the project. }\end{array}$ & & & & & & \\
\hline
\end{tabular}


11. The company was prepared for the implementation of an APS with a high degree of customization.

12. Evaluate the circumstances of the company at the time of deployment of the APS.

\section{Critical Success Factors - Supplier Requirements}

13. How many software suppliers were initially evaluated to deploy APS?

14. How do you evaluate the weight of each item below in the choice of the APS:

\begin{tabular}{|l|l|l|l|l|}
\hline \multicolumn{1}{|c|}{ Requirements } & $\begin{array}{c}\text { Unimportant } \\
(0)\end{array}$ & $\begin{array}{c}\text { Not very } \\
\text { Important } \\
(1)\end{array}$ & $\begin{array}{c}\text { Important } \\
\text { (3) }\end{array}$ & $\begin{array}{c}\text { Very } \\
\text { Important } \\
\text { (9) }\end{array}$ \\
\hline Cost of proposal & & & & \\
\hline Implementation time & & & & \\
\hline Qualification of consultants & & & & \\
\hline $\begin{array}{l}\text { Experience of consulting with } \\
\text { companies in the same industry }\end{array}$ & & & & \\
\hline Support post-deployment & & & & \\
\hline
\end{tabular}

\section{Critical Success Factors - Project Management}

\begin{tabular}{|c|c|c|c|c|c|c|c|}
\hline & Project Management & 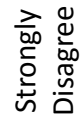 & 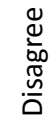 & $\begin{array}{l}\bar{\pi} \\
\frac{\sqrt[\pi]{0}}{\bar{N}} \\
\frac{0}{2}\end{array}$ & 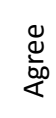 & 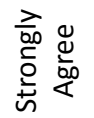 & Comments \\
\hline 15. & $\begin{array}{l}\text { The scope of the } \\
\text { project was clearly } \\
\text { defined initially. }\end{array}$ & & & & & & \\
\hline 16. & $\begin{array}{l}\text { The initial scope has } \\
\text { changed little. }\end{array}$ & & & & & & \\
\hline 17. & $\begin{array}{l}\text { The project schedule } \\
\text { was met. }\end{array}$ & & & & & & \\
\hline 18. & $\begin{array}{l}\text { Users received } \\
\text { adequate training. }\end{array}$ & & & & & & \\
\hline 19. & $\begin{array}{l}\text { The number of trained } \\
\text { users was adequate. }\end{array}$ & & & & & & \\
\hline 20. & $\begin{array}{l}\text { Company planning } \\
\text { problem is complex. }\end{array}$ & & & & & & \\
\hline 21. & $\begin{array}{l}\text { APS models fit the } \\
\text { problem of corporate } \\
\text { planning. }\end{array}$ & & & & & & \\
\hline 22. & $\begin{array}{l}\text { Parameterization of } \\
\text { APS was easily done. }\end{array}$ & & & & & & \\
\hline 23. & $\begin{array}{l}\text { The support by the } \\
\text { software vendor is } \\
\text { satisfactory. }\end{array}$ & & & & & & \\
\hline & $\begin{array}{l}\text { Once deployed, the } \\
\text { APS has undergone } \\
\text { updates. }\end{array}$ & & & & & & \\
\hline
\end{tabular}


Brazilian Journal of Operations \& Production Management

Volume 12, Número 2, 2015, pp. 280-297

DOI: 10.14488/BJOPM.2015.v12.n2.a8

25. Which were the major difficulties faced in the implementation of APS?

26. The company is struggling to fully use the APS? How to overcome the challenges?

\section{Benefits achieved with the APS:}

\begin{tabular}{|c|c|c|c|c|c|c|c|}
\hline & Benefits & 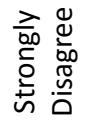 & 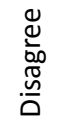 & $\frac{\pi}{\frac{\pi}{2}}$ & 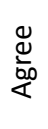 & 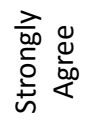 & Comments \\
\hline \multicolumn{8}{|c|}{$\begin{array}{l}\text { 27. The APS is meeting the } \\
\text { needs of the company. }\end{array}$} \\
\hline \multicolumn{8}{|c|}{ 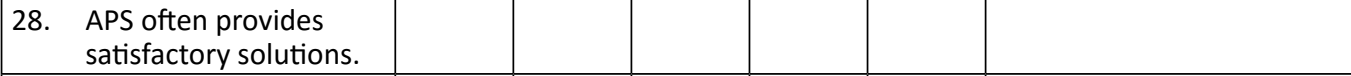 } \\
\hline \multicolumn{8}{|c|}{$\begin{array}{l}\text { 29. New solutions can } \\
\text { be easily tested by } \\
\text { managers in the APS. }\end{array}$} \\
\hline \multicolumn{8}{|c|}{ 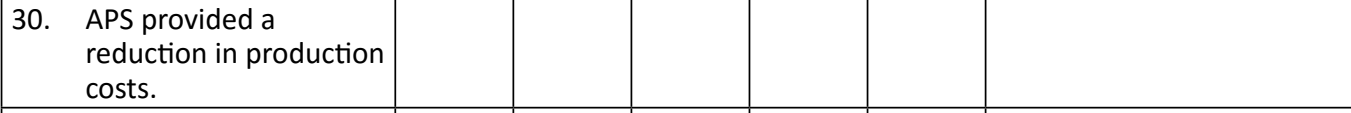 } \\
\hline \multicolumn{8}{|c|}{ 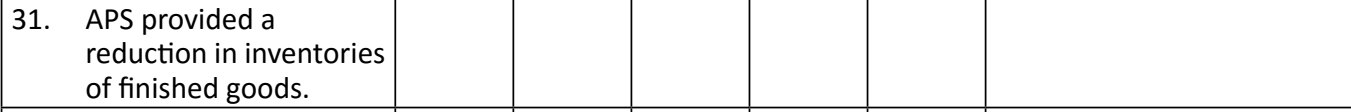 } \\
\hline \multicolumn{8}{|c|}{\begin{tabular}{|l} 
32. \\
$\begin{array}{l}\text { APS provided a } \\
\text { reduction in raw } \\
\text { material costs. }\end{array}$ \\
\end{tabular}} \\
\hline \multicolumn{8}{|c|}{$\begin{array}{ll}\text { 33. } & \text { APS provided a } \\
\text { reduction in transport } \\
\text { costs. }\end{array}$} \\
\hline \multicolumn{8}{|c|}{$\begin{array}{l}\text { 34. APS provided agility to } \\
\text { production planning. }\end{array}$} \\
\hline \multicolumn{8}{|c|}{$\begin{array}{l}\text { 35. APS has expanded the } \\
\text { possibilities for analysis } \\
\text { of scenarios. }\end{array}$} \\
\hline & $\begin{array}{l}\text { The APS is integrated } \\
\text { into the planning } \\
\text { process of the } \\
\text { company. }\end{array}$ & & & & & & \\
\hline
\end{tabular}

37. Which is your overall assessment of the APS project in company? 


\section{APPENDIX 2: GUIDE FOR INTERVIEWS IN THE CONSULTING COMPANY}

The script shown below used to interview the consulting team that conducted the project to implement the APS.

\section{Identification:}

Name:

Department:

Position:

Education:

Time working in the company:

Motivation for the APS Project:

\begin{tabular}{|c|c|c|c|c|c|c|}
\hline Motivations & 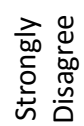 & 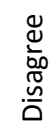 & 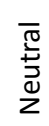 & 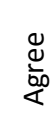 & 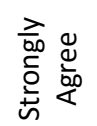 & Comments \\
\hline $\begin{array}{l}\text { 1. APS was implemented } \\
\text { in order to reduce } \\
\text { production costs. }\end{array}$ & & & & & & \\
\hline $\begin{array}{l}\text { 2. APS was implemented } \\
\text { in order to reduce the } \\
\text { inventory of finished } \\
\text { products. }\end{array}$ & & & & & & \\
\hline $\begin{array}{l}\text { 3. APS was implemented in } \\
\text { order to reduce the cost } \\
\text { of raw materials. }\end{array}$ & & & & & & \\
\hline $\begin{array}{l}\text { 4. APS was implemented } \\
\text { in order to reduce } \\
\text { transportation costs. }\end{array}$ & & & & & & \\
\hline $\begin{array}{ll}\text { 5. APS was implemented } \\
\text { aiming at greater } \\
\text { flexibility in planning. } \\
\end{array}$ & & & & & & \\
\hline $\begin{array}{l}\text { 6. APS was implemented to } \\
\text { complement the features } \\
\text { of ERP. }\end{array}$ & & & & & & \\
\hline
\end{tabular}

7. There were other motivations for the implementation of APS? What?

\section{Critical Success Factors - Company Requirements}

\begin{tabular}{|c|c|c|c|c|c|c|}
\hline Requirements & 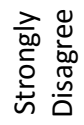 & 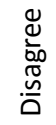 & $\begin{array}{l}\bar{\pi} \\
\frac{\sqrt[\pi]{5}}{3} \\
\frac{0}{2}\end{array}$ & $\frac{\mathbb{\Xi}}{\frac{\Phi}{40}}$ & 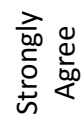 & Comments \\
\hline $\begin{array}{l}\text { 8. Senior management has } \\
\text { committed to the APS } \\
\text { project. }\end{array}$ & & & & & & \\
\hline $\begin{array}{l}\text { 9. The company shows } \\
\text { concern for operational } \\
\text { efficiency. }\end{array}$ & & & & & & \\
\hline $\begin{array}{l}\text { 10. The company had } \\
\text { qualified personnel to } \\
\text { manage the project. }\end{array}$ & & & & & & \\
\hline
\end{tabular}




\section{The company was prepared for the implementation of an APS with a high degree of customization.}

12. Evaluate the circumstances of the company at the time of deployment of the APS.

\section{Critical Success Factors - Supplier Requirements}

13. Other suppliers were consulted by the client company to provide APS?

14. How do you evaluate the weight of each item below in the APS decision to choose your company:

\begin{tabular}{|l|l|l|l|l|}
\hline \multicolumn{1}{|c|}{ Requirements } & $\begin{array}{c}\text { Unimportant } \\
\text { (0) }\end{array}$ & $\begin{array}{c}\text { Not very } \\
\text { Important } \\
(1)\end{array}$ & $\begin{array}{c}\text { Important } \\
\text { (3) }\end{array}$ & $\begin{array}{c}\text { Very } \\
\text { Important } \\
\text { (9) }\end{array}$ \\
\hline Cost of proposal & & & & \\
\hline Implementation time & & & & \\
\hline Qualification of consultants & & & & \\
\hline $\begin{array}{l}\text { Experience of consulting with } \\
\text { companies in the same industry }\end{array}$ & & & & \\
\hline Support post-deployment & & & & \\
\hline
\end{tabular}

\section{Critical Success Factors - Project Management}

\begin{tabular}{|c|c|c|c|c|c|c|c|}
\hline & Project Management & 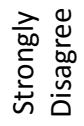 & 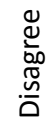 & $\begin{array}{l}\overline{0} \\
\frac{0}{5} \\
\frac{0}{2} \\
2\end{array}$ & 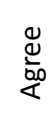 & 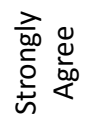 & Comments \\
\hline 15. & $\begin{array}{l}\text { The scope of the } \\
\text { project was clearly } \\
\text { defined initially. }\end{array}$ & & & & & & \\
\hline 16. & $\begin{array}{l}\text { The initial scope has } \\
\text { changed little. }\end{array}$ & & & & & & \\
\hline \begin{tabular}{|l}
17. \\
\end{tabular} & $\begin{array}{l}\text { The project schedule } \\
\text { was met. }\end{array}$ & & & & & & \\
\hline 18. & $\begin{array}{l}\text { Users receive adequate } \\
\text { training. }\end{array}$ & & & & & & \\
\hline \begin{tabular}{|l}
19. \\
.
\end{tabular} & $\begin{array}{l}\text { The number of trained } \\
\text { users was adequate. }\end{array}$ & & & & & & \\
\hline 20. & $\begin{array}{l}\text { Company planning } \\
\text { problem is complex. }\end{array}$ & & & & & & \\
\hline 21. & $\begin{array}{l}\text { APS models fit the } \\
\text { problem of corporate } \\
\text { planning. }\end{array}$ & & & & & & \\
\hline 22. & $\begin{array}{l}\text { Parameterization of } \\
\text { APS was easily done. }\end{array}$ & & & & & & \\
\hline 23. & $\begin{array}{l}\text { The support provided } \\
\text { for operation of the } \\
\text { APS was satisfactory. }\end{array}$ & & & & & & \\
\hline \begin{tabular}{|l}
24. \\
\end{tabular} & $\begin{array}{l}\text { Once deployed, the } \\
\text { APS has undergone } \\
\text { updates. }\end{array}$ & & & & & & \\
\hline
\end{tabular}


25. Which were the major difficulties faced in the implementation of APS?

26. Improvements are planned for the APS? How these improvements will be transferred to the client company?

Benefits achieved with the APS:

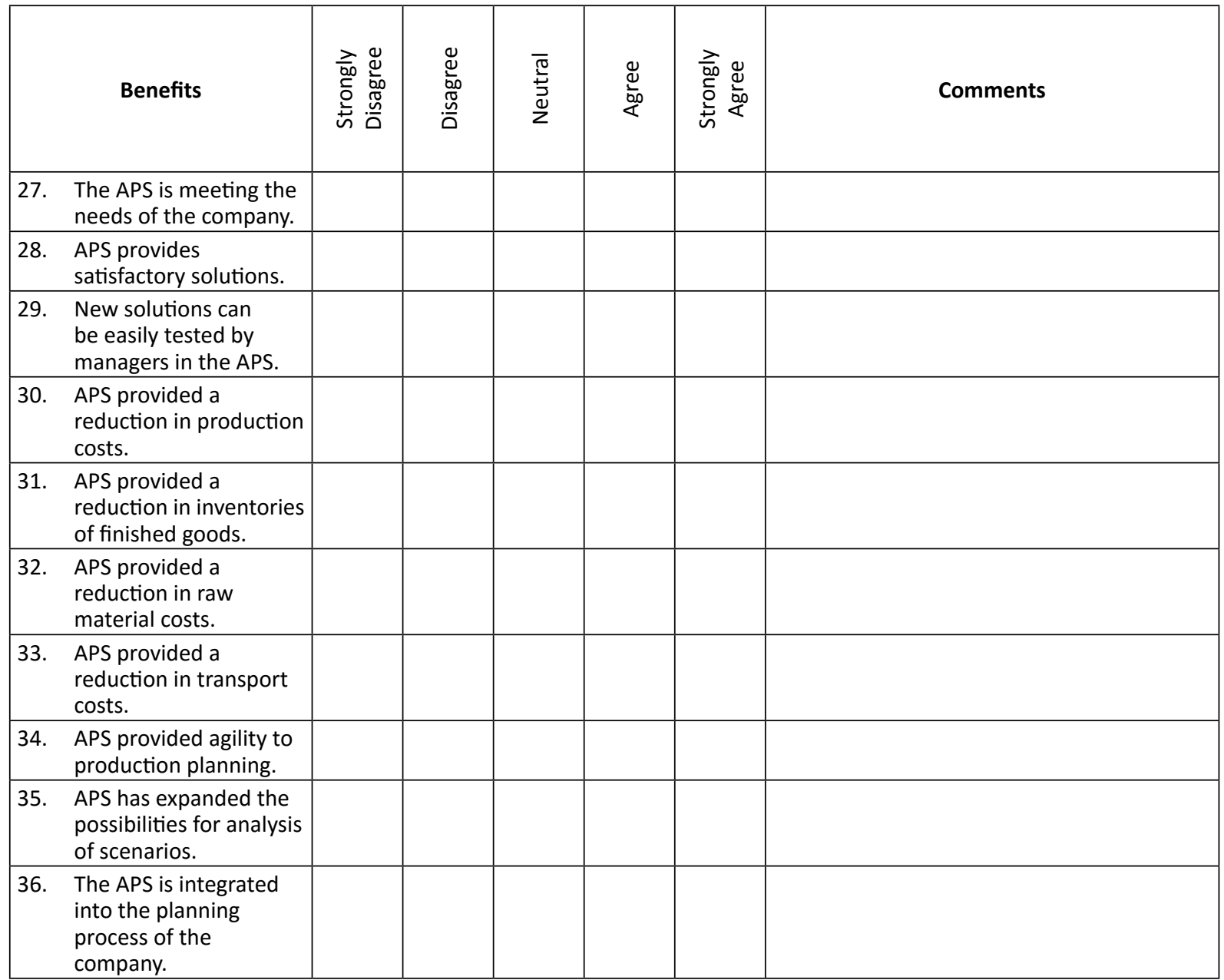

37. Which is your overall assessment of the APS project in company? 